Rafat Tyszkiewicz ${ }^{1}$

\title{
IMPLEMENTACJA KULTURY ZARZĄDZANIA W PRZEDSIĘBIORSTWIE PRODUKCYJNYM
}

\begin{abstract}
Streszczenie: Prezentowany artykuł podejmuje problematykę wzajemnego związku między kulturą zarządzania $\mathrm{i}$ jej wpływie na styl zarządzania menedżera $\mathrm{w}$ przedsiębiorstwie. U podstaw wprowadzonych wniosków leży założenie, że kultura zarządzania jest determinantą mającą kluczowe znaczenie w kontekście sprawowanego stylu zarządzania menedżera.
\end{abstract}

Słowa kluczowe: kultura organizacyjna, kultura zarządzania, menedżer.

\section{Wprowadzenie}

Menedżerowie przedsiębiorstw $\mathrm{w}$ poszukiwaniu przewagi konkurencyjnej uczestniczą w wyścigu technologicznym, ekonomicznym i osobowym. Wymuszają przemianę $\mathrm{w}$ środowisku biznesowym, w którym często pomijany jest aspekt kultury zarządzania.

W warunkach zaostrzonej konkurencji menedżerowie przedsiębiorstw włączają nowe elementy, które pozwalają rozwijać całe przedsiębiorstwo, a nie tylko wąskie jego zakresy. Takim elementem jest między innymi kultura organizacji, a w szczególności podrzędna jej kultura zarządzania. W większości przypadków twórcą pierwowzoru kultury jest jej założyciel, ponieważ posiada on $\mathrm{z}$ reguły określone poglądy na temat jej funkcjonowania oraz jej charakteru. Narzuca swoją wizję wszystkim, którzy wchodzą $\mathrm{w}$ skład organizacji. Jeżeli menedżer przedsiębiorstwa jest agresywny i przedsiębiorczy to organizację cechuje skłonność do podejmowania ryzyka i innowacyjność; a jeżeli na jej czele będzie stał biurokrata to organizacja i stosunki w niej panujące będą bardzo sformalizowane, a rozwój będzie ograniczony.

Wydaje się być prawdziwa teza, iż kultura zarządzania wpływa na styl zarządzania $\mathrm{w}$ przedsiębiorstwie. Przyjmując tę tezę, zaprezentowano $\mathrm{w}$ niniejszym artykule próbę identyfikacji kultury zarządzania w 38 przedsiębiorstwach z branży produkcyjnej z województwa dolnośląskiego.

\footnotetext{
${ }^{1}$ Dr, Wyższa Szkoła Bankowa we Wrocławiu, e-mail: rafal.tyszkiewicz@wsb.wroclaw.pl ORCID ID: 0000-0003-1525-0697.
} 


\section{Kultura organizacyjna a kultura zarządzania}

Wyjaśniając pojęcie „kultura zarządzania” należy zwrócić uwagę na pojęcie „kultura organizacyjna” z uwagi na fakt, że oba te pojęcia odnoszą się do organizacji społecznej, a taką organizacją jest zakład pracy, przedsiębiorstwo produkcyjne.

W pracy różnych autorów spotyka się wiele definicji terminu kultura organizacyjna. H. Schein zinterpretował termin ten jako zespół rozsądnych reguł postępowania, odkrytych, ustanowionych i rozwiniętych przez grupę, służących do zmagania się z problemami wewnętrznej integracji i zewnętrznym dostosowaniem, które dzięki wystarczająco dobremu działaniu wytyczają nowym pracownikom sposób myślenia i odczuwania w aspekcie wspomnianych problemów [1]. Autor powyższego terminu kultury organizacyjnej stworzył model kultury organizacyjnej, w którym poszczególne elementy składowe kultury organizacyjnej zostały wyróżnione na podstawie dwóch kryteriów: łatwość obserwacji (widoczność) i stopień ich uświadomienia (trwałość), a następnie pogrupowane w trzy poziomy: artefakty (symbole), normy i wartości, założenia podstawowe. Gdzie, symbole to słowa, gesty, obrazy i przedmioty o szczególnym znaczeniu. Są one rozpoznawalne i jednakowo odbierane przez tych, którzy należą do danego typu organizacji (np. sposób ubierania się, znak firmowy). Wartości są to różnego rodzaju przekonania, które określają sposób zachowania się członków danej organizacji jako najbardziej ceniony. Normy są praktyczną realizacją przyjętych wartości. Przez zachowania ludzi w organizacji uzewnętrzniają się podstawy i wartości preferowane w danej zbiorowości [2].

A. Pocztowski definiuje kulturę organizacyjną jako utrwalony wzorzec, podzielanych przez członków danej organizacji, założeń, wartości, norm i sposobów radzenia sobie z doświadczeniami, które zostały wypracowane, odkryte lub stworzone w toku jej rozwoju i które manifestują się w określonym zachowaniu jej członków [3].

Do głównych funkcji kultury organizacyjnej należy zaliczyć [4]:

- umożliwienie zrozumienia misji i strategii organizacji oraz identyfikacji podstawowego celu organizacji przez uczestników,

- umożliwienie integracji uczestników,

- umożliwienie integracji wokół środków przyjętych dla realizacji celów firmy oraz zwiększenie zaangażowania pracowników,

- umożliwienie stosowania jednolitych sposobów pomiaru i kryteriów oceny efektów,

- umożliwienie polepszenia sposobów działania i przeformułowania celów, jeśli potrzebna jest zmiana,

- oferowanie wspólnego języka i aparatu pojęciowego,

- definiowanie granic grupy, kryteriów przyjęcia i odrzucenia, umożliwienie kształtowania granic między grupami, 
- wyznaczanie zasad władzy i kryteriów statusu, umożliwienie unikania konfliktów na tle władzy, negatywnych emocji, agresywnych działań,

- określenie sposobu uzyskania autorytetu,

- $\quad$ określenie jak i kiedy można krytykować osoby sprawujące władzę, ich decyzje i propozycje.

Kultura organizacyjna wymaga różnych dóbr (nakładów), aby mogła przetrwać. Jej siła częściowo zależy od okoliczności natury ekonomicznej, które podtrzymują przedsiębiorczość i wysiłek twórczy, od tego, czy osiągalne są cele produkcyjne oraz od wyzyskania i ochrony zasobów naturalnych [5]. Zatem kultura ta spełnia potrzeby bezpieczeństwa, przynależności i przewidywalności. Jest ona swoistym spoiwem utrzymującym organizację $\mathrm{w}$ całości i dającym pracownikom wiele radości z pracy w konkretnym przedsiębiorstwie i tam zatrudnionymi ludźmi [6]. Wpływa znacznie na postawy $\mathrm{i}$ zachowania pracowników, a jej rola jest niekwestionowana $\mathrm{w}$ zarządzaniu przedsiębiorstwem.

Do tej pory kultura organizacyjna rozumiana była raczej jako statyczna i przystosowująca się do otoczenia, a nie zmieniająca go [2]. Zmiany zachodzące w gospodarce, technologiach i procesach społecznych wymuszają kreowanie nowych modeli organizacji, które pozwalałyby lepiej wyjaśniać zachodzące w nich procesy oraz stanowić podstawę praktycznych wskazówek dla grup zarządzających [7].

Kultura zarządzania mieści się w szerszym określeniu „kultura organizacji”, gdyż, przede wszystkim obejmuje kształtowanie wzajemnych relacji i stosunków międzyludzkich między pracownikami, a kierownictwem firmy, ale jednocześnie kładzie szczególny nacisk na przekonania i wartości jakimi odznaczają się menedżerowie w procesie budowania kultury przedsiębiorstwa, którym kierują.

J. Stachowicz, J. Machulik jedni z pierwszych autorów zdefiniowali pojęcie kultury zarządzania. W ich rozumieniu kultura zarządzania (management culture) to pojęcie odnoszące się bardziej do procesu zarządzania niż do działań całej organizacji, utożsamiane często z kulturą kadry zarządzającej [8]. Jest to odkrywcze stwierdzenie i należy, zauważyć, że kultura zarządzania to system indywidualnych wartości, postaw, percepcji menedżera przedsiębiorstwa $\mathrm{w}$ odniesieniu do funkcji zarządzania (planowania, organizowania, motywowania, kontrolowania). Kultura ta jest trwała, stabilna i odporna na zmiany oraz wpływa $\mathrm{w}$ dużym stopniu na zachowanie pracowników przedsiębiorstwa.

Wielu menedżerów rozpoczynając zarządzanie przedsiębiorstwami, nie potrafi zrozumieć, dlaczego ich pracownicy funkcjonują inaczej niż oni. Starają się więc podejmować inicjatywę wprowadzając własne, dobrze sobie znane standardy i wartości tworząc nową kulturę zarządzania w przedsiębiorstwie. W wyniku pracy menedżerów, którzy kreują kulturę zarządzania zorientowaną na kształtowanie kapitału ludzkiego wartość przedsiębiorstwa wzrasta niebywale. 
Jakościowe zmiany w kulturze pracy współczesnego menedżera ukierunkowane są na: wzrost potencjału intelektualnego, nabywanie unikalnych umiejętności potrzebnych do integracji pracowników do osiągania celów indywidualnych i zespołowych umiejscowionych $\mathrm{w}$ strategii i misji zakładu pracy [9]. W tym kontekście rangi nabiera kwestia odpowiedzialności zarządzających najwyższego szczebla, którzy osobiście reprezentują własną osobę przed pracownikami, klientami, a tym samym są odpowiedzialni za jakość kultury zarządzania w swoich przedsiębiorstwach. To oni odpowiadają za promowanie oczekiwanych wartości, definiowanie nieakceptowalnych i egzekwowanie właściwych postaw i zachowań podległej im kadry menedżerskiej

\section{Wyniki badań własnych}

Badania przeprowadzono w 38 przedsiębiorstwach produkcyjnych na próbie 43 menedżerach. Ze względu na niski dobór próby badanie ma charakter eksploracyjny jego wynikiem jest opis ważnych faktów lub zależności empirycznych, które w przyszłości mogą być stymulacją do kreacji teorii kultury zarządzania.

Przyjętą techniką badawczą był wywiad kwestionariuszowy. Objęci zostali nim menedżerowie przedsiębiorstw produkcyjnych z terenu województwa dolnośląskiego. W ramach procedury badawczej prowadzono poszukiwania nad odpowiedzią na następujące pytania:

1. Jaki typ kultury organizacyjnej opisuje sposób działania przedsiębiorstwa?

2. Czy menedżerowie angażują się $\mathrm{w}$ budowanie kultury zarządzania w przedsiębiorstwie?

3. Który styl zarządzania menedżera skutecznie wzmacnia współpracę na płaszczyźnie menedżer-podwładny?

W wyniku przeprowadzonych badań dokonano diagnozy istniejącej kultury organizacyjnej w badanych przedsiębiorstwach produkcyjnych. Wyniki badań wskazują na dominującą kulturę jednostki $(53,5 \%)$, w której stosunki międzyludzkie są bardzo ważne i cechuje je serdeczność. Kulturę tą wyróżnia dobra komunikacja (odpowiadanie na korespondencję, odbieranie telefonów) oraz nieustający koleżeński kontakt osobisty na linii przełożony - podwładny. Organizacja o kulturze jednostki zorientowana jest na zaspokojenie ludzkich potrzeb zarówno indywidualnych, jak i zbiorowych, a także dąży do zapewnienia właściwego poziomu życia pracujących w niej pracowników.

$16,3 \%$ respondentów wskazało na kulturę roli opartej przede wszystkim na wysokim stopniu biurokracji, dążeniu do osiągnięcia ładu, stabilności i racjonalności, a także biurokratycznego porządku w sensie zarówno pozytywnym, jak i negatywnym. Efektywność w tej kulturze zależy od racjonalnego wyznaczania celów 
i przydziału środków dla poszczególnych komórek. Tego typu kultura sprawdza się w otoczeniu stabilnym, kiedy cele nie zmieniają się co często i można tworzyć wyspecjalizowane komórki dla każdego z nich.

Taki sam wynik 16,3\% w badanej próbie dokonali menedżerowie wyboru kultury zadania, gdzie $\mathrm{w}$ głównej mierze władza wynika $\mathrm{z}$ doświadczenia zawodowego i wiedzy menedżera. W organizacji tej stawia się na zarządzanie talentami poprzez maksymalne wykorzystanie ich potencjału. Główną zaletą tej kultury jest jej wielka elastyczność i możliwość przystosowywania się do zmiennych warunków zachodzących w otoczeniu zewnętrznym i wewnętrznym organizacji.

$13,9 \%$ respondentów wskazało na kulturę władzy, w której to kulturze menedżer wywiera silny wpływ na organizację i dobiera zaufanych pracowników według własnych interesów. W kulturze tej decyzje podejmowane są tylko i wyłącznie pod wpływem menedżera przedsiębiorstwa. Występujący tu duży dystans władzy wpływa na fakt, że menedżer posiada pełną kontrolę i informację nad podejmowanymi działaniami w przedsiębiorstwie. Władza zależy raczej od formalnej pozycji w strukturze organizacji, niż cech osobowościowych.

Tabela 1. Typy kultury organizacyjnej

\begin{tabular}{|c|c|c|}
\hline \multirow{2}{*}{ Typ kultury organizacyjnej } & \multicolumn{2}{c|}{$\begin{array}{c}\text { Udzielone } \\
\text { odpowiedzi }\end{array}$} \\
\cline { 2 - 3 } & liczba & \% \\
\hline $\begin{array}{c}\text { WŁADZY - władza wywiera silny wpływ na organizację i dobiera zaufanych } \\
\text { pracowników według własnych interesów, decyzje podejmowane pod } \\
\text { wpływem lidera. Pełnia kontroli i informacji znajduje się we władzy osób. }\end{array}$ & 6 & $13,9 \%$ \\
\hline $\begin{array}{c}\text { ROLI - każdy ma swoją rolę, współpraca oparta na procedurach i zakresach } \\
\text { czynności, władza zależy od formalnej pozycji w organizacji, niż cech } \\
\text { osobowościowych, rola pracownika jest ważniejsza niż osoba, która ją pełni. }\end{array}$ & 7 & $16,30 \%$ \\
\hline $\begin{array}{c}\text { ZADANIA - nacisk kładzie się na to by praca została wykonana, duży nacisk } \\
\text { na współpracę pomiędzy zatrudnionymi, władza wynika z wiedzy i }\end{array}$ & 7 & $16,30 \%$ \\
doświadczenia, wysoka motywacja, maksymalne wykorzystanie talentów. & & \\
\hline $\begin{array}{c}\text { JEDNOSTKI - jednostka stanowi centrum, a rola firmy sprowadza się do } \\
\text { zorganizowania wygodnego miejsca pracy, zaspakaja się indywidualne i } \\
\text { zbiorowe potrzeby, występuje dobra komunikacja, zaangażowanie i } \\
\text { samorealizacja. }\end{array}$ & 23 & $53,50 \%$ \\
\hline
\end{tabular}

Źródlo: opracowanie własne

Kolejnym pytaniem zadanym menedżerom przedsiębiorstw było czy menedżerowie angażują się $\mathrm{w}$ budowanie kultury zarządzania $\mathrm{w}$ przedsiębiorstwie? Badanie empiryczne wskazuje, że ponad 93\% respondentów, zgadza się bądź całkowicie się zgadza, iż $\mathrm{w}$ zarządzaniu stosują normy, wartości i założenia 
kulturowe, które odnoszą się do: natury człowieka, relacji międzyludzkich, relacji organizacji z otoczeniem. Warto pamiętać, że osobista integralność w budowaniu kultury zarządzania wiąże się z kierunkami menedżera takimi jak: życie swoimi wartościami, które wzbudza mu wielki szacunek od kluczowych zainteresowanych stron (personelu, konkurentów, klientów, doradców). 2,3\% badanych menedżerów nie zgodziło się $\mathrm{z}$ zadanym pytaniem, natomiast $4,6 \%$ nie miało zdania na temat zaangażowania w budowie kultury zarządzania w przedsiębiorstwie.

Tabela 2. Czy menedżerowie angażują się w budowanie kultury zarządzania w przedsiębiorstwie?

\begin{tabular}{|c|c|c|}
\hline \multirow{2}{*}{$\begin{array}{c}\text { W zarządzaniu stosuje się normy, wartości i założenia } \\
\text { kulturowe odnoszące się do: natury czlowieka, relacji } \\
\text { międzyludzkich, relacji organizacji z otoczeniem }\end{array}$} & \multicolumn{2}{|c|}{ Udzielone odpowiedzi } \\
\cline { 2 - 3 } & liczba & $\%$ \\
\hline Całkowicie się nie zgadzam & 0 & $0 \%$ \\
\hline Nie zgadzam się & 1 & $2,3 \%$ \\
\hline Nie mam zdania & 2 & $4,6 \%$ \\
\hline Zgadzam się & 11 & 25,6 \\
\hline Całkowicie się zgadzam & 29 & 67,5 \\
\hline
\end{tabular}

Źródto: opracowanie własne

Skuteczność stosowanego stylu zarządzania podnosi fakt, iż znajomość zasad, norm i wartości kultury organizacyjnej sprzyja lepszej komunikacji w stosunkach menedżer - podwładni, ułatwia właściwe rozpoznanie sytuacji i atmosfery $\mathrm{w}$ organizacji, a to z kolei pozwala na właściwy dobór stylu kierowania oraz podejmowanie decyzji na szczeblu bezpośrednich kontaktów pomiędzy menedżerem a podległymi mu pracownikami, jak i tych o charakterze strategicznym, podejmowanych na najwyższych szczeblach zarządzania w organizacji. Ponad $80 \%$ respondentów przywiązuję wagę do tego stylu zarządzania demokratycznego $\mathrm{w}$ przedsiębiorstwie produkcyjnym. $16,3 \%$ respondentów wskazała na styl autokratyczny. Na styl liberalny nie udzielono żadnej odpowiedzi. W badanych przedsiębiorstwach zauważa się, że poszukuje się charyzmatycznych i kreatywnych menedżerów, samodzielnych ale $\mathrm{w}$ ramach ustalonych granic $\mathrm{w}$ przedsiębiorstwie. Dystans tych granic zależy od wielkości przedsiębiorstwa, różnic wiekowych pomiędzy pracownikami, funkcji czy stylu zarządzania, preferowanego przez przełożonego. Wreszcie - od panujących w przedsiębiorstwie obyczajów, specyfiki jej kultury organizacyjnej, a także od kultury zarządzania. 
Tabela 3. Który styl zarzqdzania menedżera skutecznie wzmacnia wspótpracę na plaszczyźnie menedzer-podwladny?

\begin{tabular}{|c|c|c|}
\hline Styl zarządzania & \multicolumn{2}{|c|}{ Udzielone odpowiedzi } \\
\cline { 2 - 3 } & liczba & $\%$ \\
\hline $\begin{array}{c}\text { Demokratyczny- zakłada, że najważniejsza jest grupa jako } \\
\text { całość. Lider demokratyczny liczy się z sugestiami } \\
\text { członków grupy }\end{array}$ & 35 & 81,4 \\
\hline $\begin{array}{c}\text { Autokratyczny- zakłada, że najważniejszy w strukturze jest } \\
\text { lider. Sam podejmuje decyzje za grupę, nie bierze udziału w } \\
\text { pracach grupy }\end{array}$ & 8 & 18,6 \\
\hline $\begin{array}{c}\text { Liberalny- zakłada, że przełożony daje swobodę w } \\
\text { planowaniu i organizowaniu zadań członkom grupy którą } \\
\text { kieruje. Stara się nie podejmować żadnych decyzji }\end{array}$ & 0 & 0 \\
\hline
\end{tabular}

Źródto: opracowanie własne

\section{Podumowanie}

Konkludując, typologia postaw menedżerów przedsiębiorstw produkcyjnych objęła menedżerów działających $\mathrm{w}$ obrębie kultury zarządzania, która stanowi fundament kultury osobistej menedżera. $\mathrm{Na}$ fundamencie tej kultury została ukształtowana etyka zawodowa menedżera. Rozciąga się ona do pielęgnowania kultury zarządzania, jako kultury organizacji i kultury osobistej. W każdej z tych wersji obserwuje się powiązania wartości ekonomicznych i wartości moralnych. Implementacja kultury zarządzania nastawionej na pracowników jest ściśle związana $\mathrm{z}$ ciągłym doskonaleniem relacji opartych na wzajemnym zaufaniu oraz wzajemnej współpracy w przedsiębiorstwie produkcyjnym. Wzory pożądanej kultury zarządzania menedżer może skutecznie zaszczepić w swoim stylu zarządzania, który często wyłania się z stylu demokratycznego, którego istotą jest postrzeganie zespołu jako całości. Menedżer zarządzający z jednej strony dąży do wykonania zadań w sposób jak najbardziej efektywny, ale $z$ drugiej pozastawia pracownikom wiele swobody $i$ jest otwarty na dialog z nimi. Przekłada się to na pozytywna atmosferę w zespole oraz zaufanie do przełożonego. Wybór stylu kierowania optymalnego względem sytuacji jest kluczową kwestią przy dbaniu o efektywność wykonywanych przez pracowników działań.

Obecnie organizacje zaczynają dostrzegać kluczową rolę rozwijania samoświadomości wśród menedżerów, jako pierwszego kroku w doskonaleniu kultury zarządzania. Zjawisko to można zaobserwować podczas wzrostu zainteresowania 
szkoleniami kadry zarządzającej wyższego szczebla. Podstawą doskonalenia kultury zarządzania jest oddziaływanie na podnoszenie umiejętności i poziomu wiedzy oraz oddziaływanie na postawy kadry kierowniczej. Pomagają one $\mathrm{w}$ stworzeniu odpowiedniej kultury zarządzania, na którą należy zwrócić uwagę $\mathrm{w}$ czasie doskonalenia kompetencji kierowniczych.

Reasumując, kulturę zarządzania można uznać jako antidotum, które wpływa w dużym stopniu na zachowanie pracowników przedsiębiorstwa, co przyczynia się między innymi na skuteczność ich pracy, komunikację a także większą efektywność.

\title{
Bibliografia
}

[1.] Schein E.H., Organizational Culture and Leadership, Jossey-Bass Publisher, San Francisco 2004, s.59.

[2.] Kożusznik B., Zachowania człowieka w organizacji, PWE, Warszawa 2011, s.282.

[3.] Pocztowski P., Zarządzanie zasobami ludzkimi, PWE, Warszawa 2003, s. 77.

[4.] Sułkowski Ł., Procesy kulturowe w organizacjach, Dom Organizatora, Toruń 2002.

[5.] Kuc B.R., Zarządzanie przywódcze, Wydawnictwo Menedżerskie PTM, Warszawa 2014, s.57.

[6.] Czerska M., Zmiana kulturowa w organizacji. Wyzwania dla współczesnego menedżera, Difin, Warszawa 2002, s. 46-47.

[7.] Zbiegień-Maciąg L., Nowe modele kultury organizacyjnej w kontekście wyzwań XXI wieku, [w:] B. Kożusznik, Kapitał ludzki w dobie integracji i globalizacji, Uniwersytet Śląski, Katowice 2005.

[8.] Stachowicz J., J. Machulik J., Kultura organizacyjna przedsiębiorstw przemysłowych, Wydawnictwo Zumacher, Katowice 2001, s. 26.

[9.] Mielczarek S., Kultura pracy menedżera, Placet, Warszawa 2010, s.11.

\section{IMPLEMENTATION OF MANAGEMENT CULTURE IN A PRODUCTION ENTERPRISE}

\begin{abstract}
The article addresses the issue of mutual relationship between management culture and its impact on the management style exercised in an enterprise. The basis for conclusions was the assumption that the management culture is a key determinant in the context of the managerial style.
\end{abstract}

Key words: organizational culture, management culture, manager 
Data przestania publikacji do Redakcji: 10.04.2019 Data akceptacji publikacji przez Redakcję: 21.05.2019 DOI: 10.30657/qpi.2019.11.01 